\title{
Does the Common Law Power to grant Cross-border Insolvency Assistance apply to an Insolvency Winding-Up that is Voluntary? The Reaction to Singularis from Singapore and Hong Kong
}

\author{
Charles Zhen Qu* and Andrew Godwin**
}

\begin{abstract}
In many common law jurisdictions, the common law power of courts to grant assistance in respect of foreign insolvency proceedings exists independently of statute. The nature of the power, however, continues to generate debate. Obiter dicta of the Privy Council suggest that no assistance is available where the foreign proceeding is a voluntary winding-up. This article evaluates the position by reference to Singapore and Hong Kong decisions and concludes that a refusal to grant assistance in circumstances involving an insolvent voluntary winding-up is inconsistent with the principle of modified universalism and that a broader recognition test should be adopted.
\end{abstract}

\section{Introduction}

As Lord Sumption observed In Singularis Holdings Ltd v PricewaterhouseCoopers: ${ }^{1}$

"in a world of global business it is in the interest of every country that companies with transnational assets and operations should be capable of being wound up in an orderly fashion under the law of the place of their incorporation and on a basis that will be recognised and effective internationally”.

A winding up of companies with transnational assets and operations in the fashion that Lord Sumption describes requires judicial assistance to be granted to representatives of foreign insolvency proceedings "without waiting for such co-operation to be sanctioned by international convention." 2 Although recognition of the foreign insolvency proceeding (or a foreign judgment) can also be understood as a form of assistance granted to the foreign court, the "judicial assistance" referred to in the preceding sentence means "the grant of additional relief beyond mere recognition in support of foreign insolvency proceedings.”3

\footnotetext{
*Associate Professor, School of Law, City University of Hong Kong. Email: <czqu00@cityu.edu.hk>.

Associate Professor, Melbourne Law School, University of Melbourne, Australia. Email: <a.godwin@unimelb.edu.au>.

${ }^{1}$ [2015] AC 1675 (PC), 1696.

${ }^{2}$ Crédit Suisse Fides Trust v Cuoghi [1998] QB 818, 827 (per Millett LJ).

${ }^{3}$ Gabriel Moss, Ian Fletcher and Stuart Isaacs, Moss, Fletcher and Isaacs on the EU Regulation on Insolvency Proceedings (3rd edn) (OUP, 2016), 100. For the difference between the recognition of a foreign proceeding, see $100 \mathrm{ff}$.
}

This is the author manuscript accepted for publication and has undergone full peer review but has not been through the copyediting, typesetting, pagination and proofreading process, which may lead to differences between this version and the Version of Record. Please cite this article as doi: 10.1002/iir.1348 
Where extensive statutory sources of powers (including the adoption of the United Nations Commission on International Trade Law (UNCITRAL) Model Law) are available (statutory jurisdictions), the common law power to grant cross-border insolvency assistance may rarely ever arise as an issue. ${ }^{4}$ This may be one of the reasons why the common law on cross-border insolvency has, for some time, been "in a state of arrested development". ${ }^{5}$ The state of development of common law on cross-border insolvency is likely to be less relevant for statutory jurisdictions. For non-statutory jurisdictions, such as some of the British offshore territories and Hong Kong, however, the shape of the common law rules may be consequential. This is due not only to the lack of statutory rules in these jurisdictions but also to the globalised nature of the economy. ${ }^{6}$ In Hong Kong, for example, close to ninety percent of the companies listed on the main board of the Hong Kong Stock Exchange were incorporated outside Hong Kong, mostly in the Cayman Islands and the British Virgin Islands. ${ }^{7}$

One of the areas where the common law has been in a state of arrested development is the law on "judicial assistance". In Singularis, ${ }^{8}$ the Privy Council identified, obiter dicta, five constraints on the availability of judicial assistance at common law. The first of these constraints (the first constraint), which says that no assistance is available where the "foreign proceeding" is one of voluntary winding-up (one that is not conducted by or on behalf of an officer of the court), has caused some controversy. Lord Neuberger, a dissenting judge in the same case, criticised this view of the majority for being "potentially arbitrary" . A number of preeminent practitioners have since expressed similar views. ${ }^{10}$ The impact of the abovementioned obiter in Singularis on the development of the law on judicial assistance, however, cannot be convincingly ascertained until the Privy Council's view expressed through that obiter is tested in subsequent cases.

The aim of this article is to evaluate the above view of the Privy Council through a discussion of two subsequent decisions in Singapore and Hong Kong, both of which involved a voluntary winding-up. Since the first constraint can be seen, as will be argued, as a precondition for the recognition of foreign insolvency proceedings (instead of a constraint on the court's discretion

\footnotetext{
${ }^{4}$ Singularis, above note 1, 1703 (per Lord Collins).

${ }^{5}$ Ian Fletcher, Insolvency in Private International Law (OUP, 1999), 93; Cambridge Gas Transportation Corpn $v$ Official Committee of Unsecured Creditors of Navigator Holdings plc [2007] 1 AC 508 (PC), [18] (per Lord Hoffmann).

6 “[T]he offshore world is quintessentially global in character”: Ian Kawaley, “Judicial Co-operation in Crossboarder Cases: Recent Offshore Developments” (2007) 20(8) Insolvency Intelligence 113, 122.

${ }^{7}$ See Hong Kong Stock Exchange, HKEX Fact Book 2018, APPENDIXES LISTED COMPANIES - MAIN BOARD, available at: <https://www.hkex.com.hk/-/media/HKEX-Market/Market-Data/Statistics/ConsolidatedReports/HKEX-Fact-Book/HKEX-Fact-Book-2018/FB_2018.pdf?la=en>.

${ }^{8}$ [2015] AC 1675 (PC).

${ }^{9}$ Singularis, above note 1,1730 .

${ }^{10}$ For example, Look Chan Ho, Cross-Border Insolvency: Principles and Practice (Sweet \& Maxwell, 2016), 230; Moss, Fletcher and Isaacs (above note 3), 106.
} 
to grant assistance), it will be assessed as a rule of recognition. The benchmark against which the evaluation will be carried out is the definition for "foreign proceedings" under the Model Law. The analysis concludes as follows:

(i) the Privy Council's dicta in Singularis arguably conflates the notions of "recognition" and judicial assistance beyond recognition;

(ii) courts in subsequent cases have been correct in refusing to adopt the Privy Council's distinction between voluntary and compulsory winding-up in determining what qualifies as "foreign insolvency proceedings"; and

(iii) the first constraint, as a recognition test, should be replaced with the test that Harris $\mathrm{J}$ has developed in a series of Hong Kong cases involving recognition and assistance. ${ }^{11}$

\section{The Limits of the Common Law Power to grant Assistance: The Privy Council's Position in Singularis}

In Singularis, two related Cayman Islands Companies (SICL and Singularis) became insolvent and winding up proceedings were opened. In the present case, which concerned the winding up of Singularis, the liquidators needed to obtain information and materials relating to the affairs of Singularis including materials that did not belong to the company, from the company's auditors, a Bermuda-based partnership ( $\mathrm{PwC}$ ). Under the relevant provision of the Cayman Islands Companies Law the Grand Court of the Cayman Islands had power to order "any person" to transfer or deliver up property or documents belonging to the company. In other words, the Grand Court did not have the statutory power to order the deliver up of materials that did not belong to the company. Under Bermuda's Companies Act 1981, however, the Bermuda court did have that power provided that the court had ordered a company that carries on business in Bermuda to be wound up.

The two potential issues that the Privy Council was facing were:

(i) whether the common law power to assist the liquidation of the Cayman Islands company enabled the Bermudan court to order PwC to deliver up the materials belonging to PwC itself; and

(ii) if this power existed, whether it should be exercised where the Cayman Islands court had no equivalent power to do so.

With regard to issue (i), the Privy Council said "yes" with a three to two majority. In relation to issue (ii), the Privy Council was unanimous that the answer was "no". In answering question (i) (in the affirmative), Lord Sumption stressed that:

"the Board would not wish to encourage the promiscuous creation of other common law powers to compel the production of information" and identified five constraints on the availability of judicial assistance, ${ }^{12}$ namely:

\footnotetext{
${ }^{11}$ See the discussion in Section E below.

12 Singularis, above note $1,1697$.
} 
(1) The power is available to assist the officers of a foreign court of insolvency jurisdiction or equivalent public officers. It would therefore not be available to assist a voluntary winding-up, which his Lordship described as a "private arrangement";

(2) The power to provide judicial assistance exists for the purposes of enabling the requesting court to transcend the territorial limits of the court's power. However, the power is not available to enable courts to do something that they could not do under the law by which they were appointed;

(3) The power is available only when it is necessary for the performance of the office-holder's functions;

(4) An order must be consistent with the substantive law and public policy of the assisting court; ${ }^{13}$ and

(5) The exercise of the power "is conditional on the applicant being prepared to pay the third party's reasonable costs of compliance.”14

While conditions (2) to (5) are arguably constraints on the availability of judicial assistance, the first constraint can be seen, and was seen in a couple of subsequent Singapore and Hong Kong decisions, as something of a test for the recognition of foreign insolvency proceedings. Under this test, a voluntary winding-up, for the reasons that Lord Sumption considered, is not recognised as a foreign insolvency proceeding, even if it is undertaken in the context of insolvency. Since recognition of the officeholder's authority is a prerequisite for granting judicial assistance, ${ }^{15}$ the court's refusal to recognise the officeholder's authority would result in a refusal to grant the assistance prayed for.

Lord Sumption did not expand on his view as to why the common law power would not be available to assist a voluntary winding-up, or why the power would not apply where the winding-up was not conducted by or on behalf of an officer of the court, even in circumstances where the winding-up was subject to the control of the court. As will be noted below, however, the statement appears to rule out insolvency representatives who are not court officers. It also appears to overlook the extent to which the focus of the common law is on the (potential) control of a court rather than the appointment of an office-holder.

Lord Clarke, another majority judge in Singularis, concurred with Lord Sumption on the latter's view referred to above. ${ }^{16}$ Insofar as they were not directly relevant to the issue raised in Singularis, however, Lord Sumption's words on the constraint on the availability of judicial assistance, with the possible exception of those under point 2, were obiter dicta.

\section{Feedback from Singapore and Hong Kong}

The issue in both the subsequent cases mentioned above, as will be seen, was whether judicial assistance should be granted where the proceeding was a voluntary winding-up. Unsurprisingly, an issue for both courts was whether the Privy Council's view on recognition should be followed. Both courts said "no". The reasons are elaborated below.

\footnotetext{
${ }^{13}$ For example, "the common law powers of this kind are not a permissible mode of obtaining material for use in actual or anticipated litigation.” Singularis, above note 1, 1697.

${ }^{14}$ Singularis, above note $1,1698$.

${ }^{15}$ See text to notes $30-30$ below.

${ }^{16}$ Singularis, above note $1,1716$.
} 


\section{A. Singapore: Gulf Pacific}

Re Gulf Pacific Shipping Ltd (in creditors' voluntary liquidation) ${ }^{17}$ was decided in 2016, before Singapore had adopted the UNCITRAL Model Law. ${ }^{18}$ There, the company was a wholly-owned subsidiary of a holding company, which had been compulsorily wound up by the Hong Kong Court. One of the liquidators of the holding company was appointed a director of the company. The company, which was incorporated in Hong Kong, was subsequently put into a creditors' winding-up. The liquidators of the company applied for recognition in Singapore to obtain bank statements from the Singapore branch of an international bank.

In granting the application, Aedit Abdullah JC refused to adopt the distinction between voluntary and compulsory winding-up that the Privy Council made obiter in Singularis. His Honour, referring to his own recent decision in Re Opti-Medics (in liquidation), ${ }^{19}$ held that the foundational doctrine in the recognition of foreign insolvency proceedings is the promotion and facilitation of the orderly distribution, as well as the orderly resolution and dissolution, of the entities being wound up and the precise mode of the winding up would therefore not generally be material. ${ }^{20}$

Aedit Abdullah JC accepted the applicants' submission that the US case In re Betcorp Ltd (in liquidation $)^{21}$ was an authority for not distinguishing between voluntary winding-up and compulsory winding-up. In Betcorp, Judge Markell of the US Bankruptcy Court held that the members' voluntary winding-up of a solvent Australian company qualified as a "foreign main proceeding" for the purposes of Chapter 15 of the US Bankruptcy Code. Chapter 15 allows cooperation between the United States courts and foreign courts, as well as other authorities of foreign countries involved in cross-border insolvency cases. As discussed further, however, the correctness of this decision can be challenged on the basis that the Australian proceeding was a solvent winding-up and not an insolvency proceeding. ${ }^{22}$

\section{B. Hong Kong: Supreme Tycoon}

In Re Joint Liquidators of Supreme Tycoon $L t d,{ }^{23}$ the foreign company, Supreme Tycoon Ltd (the Company), was incorporated in the British Virgin Islands (BVI). The Company was a wholly-owned subsidiary of China Culture Media International Holdings Ltd (China Culture), which was also incorporated in BVI. China Culture was ordered to be wound up by the East Caribbean Supreme Court.

\footnotetext{
${ }^{17}$ [2016] SGHC 287, Originating Summons No 1139 of 2016 (30 December 2016).

${ }^{18}$ Singapore adopted the Model Law in 2017.

19 [2016] 4 SLR 312.

${ }^{20}$ Ibid., [10].

${ }^{21} 400$ BR 266 (Bankr. D. Nev. 2009).

${ }^{22}$ See text to note 61 below.

${ }^{23}$ [2018] 1 HKLRD 1120.
} 
One of the joint liquidators of China Culture, acting on behalf of that company, subsequently passed a shareholders' written resolution to wind up the Company and to appoint himself and his joint liquidator of China Culture as joint liquidators of the Company. The joint liquidators of the Company applied for judicial assistance in Hong Kong to obtain, from various third parties, information, as well as books and records, about the company's affairs. There may also have been assets in Hong Kong to recover.

In his affidavit, the applicants’ BVI legal advisor explained, that, inter alia:

(i) the Company’s liquidation was an insolvent liquidation; ${ }^{24}$

(ii) the liquidation was fully supervised by the court; and

(iii) the liquidators of the company were officers of the Supreme Court of the BVI.

The issue for the Hong Kong Court was whether a foreign insolvent liquidation commenced by a shareholders' resolution was eligible for common law recognition and assistance in Hong Kong. Harris J answered the above question in the affirmative. His Lordship's decision was, as could be expected, made through a consideration of the Privy Council's view in Singularis.

According to Lord Sumption and Lord Clarke, it will be remembered, the common law power to recognise and assist foreign insolvency proceedings is not available to assist a voluntary winding-up. If this rule was to be followed, Harris $\mathrm{J}$ would have had to reject the joint liquidators' request. Technically, the proceeding in the case was a members' voluntary winding-up, albeit in the context of an insolvency liquidation.

Harris J, like Aedit Abdullah JC in Gulf Pacific, refused to follow the Privy Council's dicta, although his Lordship's reasoning was different. Harris J's decision was reached through a three-step reasoning process. First of all, the rationale underlying the common law power of assistance was modified universalism. ${ }^{25}$ Secondly, the purpose of the common Law power of assistance, as was referred to in the majority's obiter in Singularis, was to overcome the problems posed for a worldwide winding-up by the territorial limits of the power of each country's court. Finally, it was not obvious that the rationale behind, and the purposes of, the common law power of recognition and assistance would call for a distinction between compulsory and voluntary winding-up.

On why a decision on whether to grant assistance should not be based on the modes of the foreign proceeding in question, Harris $\mathrm{J}$ offered two reasons. The first was that the Privy Council's obiter objection to recognising foreign voluntary liquidation seemed to be based on the view that the liquidator for a voluntary winding-up, which the Privy Council held to be merely a "private arrangement", was not an officer of the foreign court. The Privy Council's view on this point, according to Harris $\mathrm{J}$, is unsustainable because the difference between

\footnotetext{
${ }^{24}$ No information is provided on why this members' voluntary winding-up was an insolvent liquidation.

${ }^{25}$ Referring to his own judgment in Joint Official Liquidators of A Co v B [2014] 4 HKLRD 373.
} 
compulsory and voluntary winding-up, as can be inferred from Wynn-Parry J's decision in Re Phoenix Oil and Transport Co Ltd (No. 2), ${ }^{26}$ is one of the degree of court control. The difference between the two modes of winding-up, in terms of court control, is therefore one of degree, not of kind. ${ }^{27}$

The second is that making decisions on whether assistance is warranted on the basis of whether the insolvency representatives are appointed by the court may hinder officeholders from performing their functions:

“..., the purpose of cross-border insolvency assistance consists in meeting the foreign insolvency officeholders' practical needs. As recognised by the Privy Council, the common law power of assistance is available only when it is necessary for the performance of the office-holder's functions. Where a foreign insolvency proceeding is a collective proceeding and the foreign insolvency officeholders need the Hong Kong court's assistance to discharge their functions, it would seem arbitrary and unduly restrictive to insist that they are not entitled to assistance merely because they were not appointed by the foreign court.”28 (citations omitted)

Although Harris J agreed with the outcome of Aedit Abdullah JC's decision in Gulf Pacific, he made it clear that he would not rely on the US Bankruptcy Court's decision in Betcorp, saying that it was a controversial case. As will be seen later, his Lordship was right in distancing himself from Betcorp but there should be a deeper reason than the one referred to above. $^{29}$

\section{Evaluation}

As previously mentioned, the first constraint that Lord Sumption identified concerns the recognition of foreign insolvency proceedings. It follows that that test, as well as the feedback from Hong Kong and Singapore, should be assessed against an internationally accepted notion of "foreign insolvency proceedings". The debate in this section will therefore be carried out by reference to the definition adopted in the Model Law. As:

“the current analysis of the court's common law jurisdiction conflates a number of different powers and is conceptually confused,”30

it is necessary to start the debate with a consideration of the distinction between "recognition" and "assistance".

\section{A. The Distinction between Recognition and Assistance}

\footnotetext{
${ }^{26}$ [1958] Ch 565, 570.

27 (2018) 1 HKLRD, [4].

${ }^{28}$ Ibid., [16].

${ }^{29}$ See text to note 54 below.

${ }^{30}$ Nick Segal, Jonathan Harris and Matthew Morrison, “Assistance to Foreign Insolvency Office-holders in the Conflicts of Laws: Is the Common Law Fit for Purposes” (2017) 30 (8) Insolvency Intelligence 117, 118.
} 
As the counsel for the applicants in Singularis pointed out in their submission:

\begin{abstract}
"It is necessary to distinguish between (1) "recognition" and "judicial assistance" and (2) "recognition of insolvency proceedings" and recognition of judgments. In its strict narrow sense, "recognition" refers to mandatory rules by which one jurisdiction gives direct effect in its own jurisdiction to a legal act in another. Thus, if a winding up order is made in the Cayman Islands as the place of the company's registration, Bermuda in accordance with its common law conflicts rules give effect to that to the extent of recognising the Cayman Islands liquidators as the sole authorised agents under Cayman Islands law, able to act on behalf of the company in Bermuda." 31 (citations omitted).
\end{abstract}

For the purposes of this article, the distinction that needs to be made is one between the recognition of a foreign insolvency proceeding and judicial assistance beyond recognition. The former is a precondition for the latter. The latter, as previously noted:

"involves the grant of additional relief beyond mere recognition in support of foreign insolvency proceedings." 32

\title{
B. What constitutes a "Foreign Proceeding" under the Model Law
}

The concept of foreign proceedings in the Model Law is defined in Articles 1 and 2. Article 1(a) says that the Model Law applies where, inter alia, assistance is sought by a foreign court or foreign representative in connection with a foreign proceeding. Article 2(a) defines a foreign proceeding as a:

"collective judicial or administrative proceeding in a foreign State, ... pursuant to a law relating to insolvency in which proceeding the assets and affairs of the debtor are subject to control or supervision by a foreign court, for the purpose of reorganization or liquidation". (emphasis added)

As can be seen, the constituent elements of a "foreign proceeding" for the purposes of the Model Law include:

(i) that the proceeding must be a collective proceeding;

(ii) that the proceeding must be one of insolvency; and

(iii) that the assets and affairs of the debtor must be subject to the control or supervision by a foreign court. It should be noted, however, that the Model Law definition also makes it clear that a foreign proceeding can be either a judicial or an administrative proceeding.

Mr Tom Smith QC, a preeminent insolvency practitioner, has put forward a common law definition for foreign insolvency proceedings:

"[i]t is suggested that...an insolvency proceeding will be a collective process, undertaken on behalf of creditors, often (but not necessarily) involving the appointment of an office-holder and usually taking place under the supervision of a court." ${ }^{33}$

\footnotetext{
${ }^{31}$ Singularis, above note $1,1678-9$.

${ }^{32}$ Text to note 3 above.

${ }^{33}$ Richard Sheldon QC (ed), Cross Border Insolvency (4th edn) (Bloomsbury Professional, 2015), 254.
} 
This proposed common law test, which reflects practitioners' understanding of the nature of foreign insolvency proceedings, also contains the three constituent elements of the Article 2 definition.

\section{Lord Sumption's Test}

The recognition test that Lord Sumption formulates, it will be remembered, is that the proceeding must be a compulsory winding-up. This requirement is not a constituent element of the Model Law definition of the "foreign proceeding". Nor, for the reasons elaborated below, is the addition of this requirement to the constituent elements stated in Article 2 of the Model Law justifiable.

\section{The Insolvency Representative does not need to be a Court Officer}

Article 2 of the Model Law does not say that the officeholder, for the purposes of Model Law, has to be a court officer. Article 2 says that the "proceeding” must be a collective judicial or administrative proceeding pursuant to a law of insolvency. Where the proceeding is judicial, the officeholder, being appointed by the court, tends to be a court officer. However, an administrative proceeding also qualifies as a "proceeding" under Article 2 and the officeholder appointed does not need to be a court officer.

In Betcorp, ${ }^{34}$ Judge Markell held that a voluntary winding-up was:

"a proceeding with an administrative character, although under certain circumstances the proceeding may temporarily become more appropriately characterized as judicial”. ${ }^{35}$

As his Honour pointed out:

"the initial actions of the liquidator, such as sending a notice of liquidation and requesting proofs of debts, have an administrative character."36

If an administrative proceeding qualifies as a "proceeding” for the purposes of Article 2, the fact that the officeholder is not a court officer should not, for the purposes of the Model Law, preclude the proceeding from being characterised as a "foreign proceeding".

\section{It may difficult to determine whether an Officeholder is a Court Officer}

An officeholder appointed by the court is no doubt a court officer but one who is not appointed by the court may also be a court officer. An example is the administrator for the

\footnotetext{
${ }^{34}$ See above note 20.

${ }^{35}$ Ibid., 280.

${ }^{36}$ Idem. Although Betcorp is arguably wrongly decided, there is no reason to doubt the correctness of Judge Markell's view on this issue.
} 
purposes of the UK's Administration order procedure. ${ }^{37}$ By paragraph 5 of Schedule B1 of the Insolvency Act 1986, the administrator is a court officer. An administrator, however, can be appointed either by the court or by others. ${ }^{38}$

3. Whether the Officeholder is a Court Officer does not necessarily determine whether the Proceeding is one of Insolvency

As Lord Neuberger pointed out in Singularis:

"[c]ompanies may be in court-imposed liquidation in many jurisdictions when it is "just and equitable" to wind them up, even if they are solvent... ."39

The liquidator for a "just and equitable" winding-up, which is a compulsory winding up, is undoubtedly a court officer. The proceeding, however, is not pursuant to the law of insolvency, as it is a solvent winding-up. On the other hand, as will be seen below, a creditors' winding-up or a shareholders' winding-up that is initiated by directors is not a court-imposed winding-up, yet the proceeding may be pursuant to the law of insolvency. The company, under the circumstances, is insolvent.

4. The Level of Court Control does not necessarily hinge on whether the Officeholder is a Court Officer

As previously noted, a proceeding qualifies as a "foreign proceeding" if, inter alia, the proceeding is subject to the supervision or control of the foreign court. Whether the assets and affairs of the debtor are subject to court supervision or control, however, does not necessarily hinge on whether the officeholder is appointed by the court. ${ }^{40}$ Within Commonwealth jurisdictions, the liquidator of a voluntary winding-up is not necessarily free from court supervision and control. First of all, provisions on liquidators' power may be framed in such terms that all liquidators can exercise the same powers. ${ }^{41}$ Where this is the case, liquidators other than those appointed by the court will be treated as if they are "officers of the court", as:

"it would be strange if Parliament had intended those appointed other than by the Court to be subject to less curial supervision than those in whom the Court, by its own order, has reposed confidence.” 42

Secondly, even where all liquidators are not given the same powers, the court still has control over liquidators not appointed by the court. Take Hong Kong for example. Under the insolvency regime of that region, the liquidator appointed for the purposes of a creditors' voluntary winding-up may exercise certain powers without court sanction. These include:

\footnotetext{
${ }^{37}$ See Singularis, above note 1, 1731 (per Lord Neuberger PSC); Ho, above note 10, 230.

${ }^{38}$ See paragraphs 10, 11, 14(1), 22(1), 22(2) and 105, Schedule B1, Insolvency Act 1986.

${ }^{39}$ Singularis, above note 1,1730 .

${ }^{40}$ See text to note 32 above $f f$.

${ }^{41}$ Section 260, Schedule 6, Companies Act (1993) (NZ).

${ }^{42}$ ANZ National Bank Ltd v Sheahan and Lock [2013] 1 NZLR 674, 715.
} 
(i) taking into the liquidator's custody or under the liquidator's control, all property and things in action;

(ii) disposing of perishable goods; and

(iii) doing anything necessary to protect the company's assets. ${ }^{43}$

On the other hand, an exercise of other statutory powers of a liquidator, for example, making a compromise or arrangement with creditors, carrying on the business of the company, so far as may be necessary for its beneficial winding up, or selling real or personal property and things in action of the company by public auction or private contract, ${ }^{44}$ must be sanctioned by the court, or the committee of inspection, or (if there is no such committee), a meeting of the creditors. ${ }^{45}$ Where it is necessary for the officeholder to exercise a power that requires sanction, the practitioner is under the control of the court. This is so, as will be seen, even where a sanction is sought from the committee of inspection or a meeting of the creditors. ${ }^{46}$

A more telling example in the Hong Kong context is the court supervision over a shareholders' voluntary winding-up initiated by directors. Under section 228A of the Companies (Winding Up and Miscellaneous Provisions) Ordinance (Cap 32), the directors have the power to initiate this type of voluntary winding-up by a resolution if they have formed the opinion that the company cannot by reason of its liabilities continue its business and it is not reasonably practicable for the winding-up to be commenced under another section of Cap 32. ${ }^{47}$

A provisional liquidator will be appointed (by the directors) on the commencement of section 228A winding up. The provisional liquidator appointed may exercise the three types of powers that the liquidator for a creditors' voluntary winding-up may exercise, as noted above, without the sanction of the court. ${ }^{48}$ The provisional liquidator appointed for the purposes of a section 228A winding-up, however, may not exercise the statutory powers conferred on liquidators beyond the above three types of powers without the sanction of the court. ${ }^{49}$ This fact evidences the court's control over a section 228A winding-up and explains why a section 228A winding-up cannot be described as a "private arrangement". That the law, whilst making no provisions on the qualifications for (provisional) liquidators in general, does provide for the minimum qualifications for a section $228 \mathrm{~A}$ provisional liquidator ${ }^{50}$ fortifies this view.

\footnotetext{
${ }^{43}$ Section 243A(2), Companies (Winding Up and Miscellaneous Provisions) Ordinance (Cap 32).

${ }^{44}$ Ibid., Part 1, Schedule 25.

45 Ibid., section 251.

${ }^{46}$ For further discussion on court control on creditors' voluntary liquidation, see text to note 62 below ff.

${ }^{47}$ The equivalent provision under Singapore's Companies Act is section 291.

${ }^{48}$ Sections 228B(1)(a) and 228B(3), Companies (Winding Up and Miscellaneous Provisions) Ordinance (Cap $32)$; text to note 43 above.

${ }^{49}$ Ibid., section 228B(2). This notwithstanding, the provisional liquidator may exercise the three types of powers that the liquidator for a creditors' voluntary winding up (text to note 43 above) without court sanction (section 228B(3)).

${ }^{50}$ Ibid., section 228A(8).
} 


\section{Aedit Abdullah JC's Test}

As previously noted, Aedit Abdullah JC's decision in Gulf Pacific was based on his view that the foundational doctrine in the recognition of foreign insolvency proceedings is the promotion and facilitation of the orderly distribution of assets, as well as the orderly resolution and dissolution of the affairs of the entities being wound up. ${ }^{51}$ In other words, his Honour apparently thought that the issue before him, namely, the availability of judicial assistance where the foreign proceeding was an insolvent voluntary winding-up, could be resolved by applying what he thought was a test for the recognition of foreign insolvency proceedings.

The judge refused to adopt Lord Sumption's first constraint, which, as pointed out, is a recognition test, without giving a reason for his refusal beyond pointing out that Lord Neuberger described, in Singularis, the distinction between voluntary and compulsory winding-up as potentially arbitrary. ${ }^{52}$ In refusing to adopt Lord Sumption's first constraint, Aedit Abdullah JC did not appear to appreciate the centrality of the "insolvency" element in the Model Law recognition test. His Honour's apparent endorsement of the Betcorp case, where Markell $\mathrm{J}$ held that a solvent members' voluntary winding up qualified as a foreign proceeding, is indicative of this.

In any event, the test that Aedit Abdullah JC formulated for recognition is unconvincing. First of all, his Honour did not elaborate on why the foundational doctrine of recognition of foreign insolvency proceedings was as outlined above. ${ }^{53}$ Moreover, the "foundational doctrine" that his Honour refers to appears to be similar to both the public interest on which, according to Lord Sumption, the principle of modified universalism is founded and the third constraint under Lord Sumption's formula; namely, that the power should be available only when it is necessary for the performance of the office-holder's functions. The public interest that his Lordship refers to in Singularis is said to lie:

“in the ability of foreign courts exercising insolvency jurisdiction in the place of the company's incorporation to conduct an orderly winding up of its affairs on a worldwide basis, notwithstanding the territorial limits of their jurisdiction." 54

This public interest is not really a test for the recognition of "foreign insolvency proceedings", although that principle of modified universalism is the rationale that underlies the common law power of assistance. ${ }^{55}$

\footnotetext{
51 [2016] SGHC 287, [10].

52 Ibid., [9].

${ }^{53}$ His Honour referred to his own judgement in Re Opti-Medix (in liquidation) [2016] 4 SLR 312, [17] as the authority for what he termed as "foundation doctrine in the recognition of foreign insolvency proceedings". No comments of his Honour's to this effect, however, could be found in that case.

${ }^{54}$ Singularis, above note 1, [23].

${ }^{55}$ See text to note 24 above.
} 
The commonality between what Aedit Abdullah JC refers to as the "foundational doctrine" in recognition of foreign insolvency proceedings and the third constraint under Lord Sumption's formula is that both say that the power to grant assistance is available only when it is necessary for the performance of the office-holder's functions. So arguably, what his Honour refers to as the "foundational doctrine" is just one of the further constraints on the availability of judicial assistance that Lord Sumption has identified once the recognition test (the subject of his first constraint) is satisfied.

\title{
E. Harris J's Test
}

In making his decision in Supreme Tycoon, Harris J held that:

\begin{abstract}
"what matters for cross-border insolvency assistance is not whether the foreign insolvency office holder is or is not an officer of the foreign court. What matter is whether the foreign proceeding is collective in nature, in the sense that it is "a process of collective enforcement of debts for the benefit of the general body of creditors". It is with collective insolvency proceedings that the principle of modified universalism is concerned.” (emphasis added, citations omitted)
\end{abstract}

As can be gauged from the last sentence in the above-quoted paragraph, according to Harris $\mathrm{J}$, what matters for cross-border insolvency assistance is whether the foreign proceeding is a collective insolvency proceeding. That test appears, and perhaps was meant, to be one for recognising foreign insolvency proceedings, as distinguished from one for the availability of judicial assistance (beyond mere recognition). ${ }^{56}$ His Lordship’s subsequent decisions confirm this. $^{57}$

It is submitted that as a recognition test, Harris J's version is superior to both Lord Sumption's first constraint and Aedit Abdullah JC's test. Harris J's test contains two of the three core constituent elements of the Model Law definitions of "foreign proceeding(s)", namely, the collective proceeding and the insolvency elements. A key aspect of Harris J's decision in Supreme Tycoon is the emphasis he has put on the insolvency element. For Harris $\mathrm{J}$, a proceeding would not answer the description of a foreign insolvent proceeding if it were one of solvent winding-up. A solvent winding-up would be akin to a "private arrangement" that the Privy Council referred in Singularis. ${ }^{58}$ Also, a solvent winding-up would not fall within the principle of modified universalism. ${ }^{59}$

\footnotetext{
${ }^{56}$ Moss, Fletcher and Isaacs, above note 3, 104.

${ }^{57}$ In Re CM Advanced Technology Ltd [2018] HKCFI 1705, [32] Harris J said, obiter, that "the characterization of the Singapore Moratorium for recognition purposes may well depend on whether a scheme of arrangement should be treated as a collective insolvency proceeding." (emphasis added). In Joint Provisional Liquidators of Hsing Chong Group Holdings Ltd [2019] HKCFI 805, [2] Harris held that: "[t]he law is well-settled that the Hong Kong court will recognise foreign insolvency proceedings that comply with the following criteria: the foreign insolvency proceedings are collective insolvency proceedings, etc.” (emphasis added).

${ }^{58}$ Re Joint Liquidators of Supreme Tycoon Ltd [2018] 1 HKLRD 1120, 1126 [17].

59 Idem.
} 
A further indication of the emphasis his Lordship put on the company's state of solvency is his refusal to rely on the US Bankruptcy Court's decision in Betcorp, which, it will be remembered, Aedit Abdullah JC endorsed in Gulf Pacific. Although the only reason Harris J gave for his stance on Betcorp appeared to be that the case was controversial, his Lordship's position on Betcorp is defensible on the basis that the proceeding there was a solvent windingup. It has been suggested that Betcorp was clearly wrongly decided as Markell J, in making his decision, failed to appreciate the difference between a members' winding up and a creditors' liquidation. ${ }^{60}$

In that case, Markell $\mathrm{J}$ recognised a members' winding-up as a foreign insolvent proceeding for the purposes of Chapter 15 on the ground that, under Australia's corporate insolvency regime, a members' voluntary winding-up might be converted into a creditors' winding-up (in which case the winding up would necessarily have been an insolvent one), where the liquidator found out that the company was insolvent. It was however, impossible for the members' winding-up in Betcorp to metamorphosise into a creditors' voluntary liquidation. The proceeding there was a solvent members' winding-up. ${ }^{61}$

Admittedly, Harris J's recognition test is silent on court control. That, however, is not fatal. What is more essential is that the proceeding is one of insolvency. A "foreign proceeding", as defined in the Model Law, is:

"a collective judicial or administrative proceeding in a foreign State, including an interim proceeding, pursuant to a law relating to insolvency in which proceeding the assets and affairs of the debtor are subject to control or supervision by a foreign court, for the purpose of reorganization or liquidation."62

\footnotetext{
${ }^{60}$ Look Chan Ho (ed), Cross-Border Insolvency: A Commentary on the UNCITRAL Model Law Vol I (4th edn) (Global Law and Business, 2017), 188.

${ }^{61}$ Markell J's decision in Betcorp was also wrong because he seemed to think that the Australian Securities and Investment Commission (ASIC) had a measure of control over the proceeding in question (Betcorp, [9]). His Honour proffered two reasons for this view. The first was that a liquidator was required to obtain permissions from ASIC to undertaking certain actions. The example his Honour gave was the need for a liquidator to submit a written request for destroying any books and records pursuant to ASIC Policy Statement 81, Destruction of Books (3 May 2000). His Honour was wrong on this point. A liquidator can never destroy the company's books and records in the course of a winding-up proceeding. According to section 542, Corporations Act (2001) (Australia) (CA), the books and records must be kept for a minimum of 5 years after the deregistration of the company before they can be destroyed. Early destruction after the deregistration of the company requires the permission of ASIC pursuant to section 542(3), CA and the abovementioned ASIC Policy Statement (ASIC Policy Statement 81, RG 81.5). In other words, ASIC's power under the Policy Statement is exercisable only after the deregistration of the company, not in the course of the company's winding-up. A further reason Markell J gave on ASIC's control power was that pursuant to Part 9.2, CA, the ASIC had power to remove or revoke authority of any person to be a liquidator. His Honour was wrong on this point too. Under section 1290, CA, the ASIC may cancel the registration of, inter alia, a registered liquidator upon his/her own request. Under section 1292, CA, the Companies Auditors and Liquidators' Disciplinary Board has the power, on an application by $A S I C$, to suspend or cancel the registration of a liquidator. The section 1292 power belongs to the Board, not ASIC.

${ }^{62}$ Article 2(a), Model Law.
} 
If the proceeding is not one of insolvency, it would not be one "pursuant to a law relating to insolvency". It would therefore not be treated as a "foreign proceeding" under the Model Law. Moreover, the underlying principle of the court's power of recognition and assistance is modified universalism, which is now recognised as part of the common law. ${ }^{63}$ Modified universalism, according to Lord Sumption in Singularis, is founded on the public interest in the:

“ability of foreign courts exercising insolvency jurisdiction in the place of the company's incorporation to conduct an orderly winding up of its affairs on a worldwide basis, notwithstanding the territorial limits of their jurisdiction.” ${ }^{64}$ (emphasis added).

In other words, the purposes of the court's power of recognition and assistance is to enable a foreign court to transcend the territorial limit of its insolvency jurisdiction. Hence the centrality of the "insolvency" element in the test of foreign proceedings.

Also, if the proceeding is one of insolvency, the assets and affairs of the company would, arguably, necessarily be subject to a certain level of court control, depending on the nature of the proceeding (e.g. the mode of a winding-up). In an insolvency winding up, the proceeding is of course under the supervision of the court. In a shareholders' (insolvent) winding-up initiated by directors, as discussed, the court exercises a high degree of control. ${ }^{65}$ Even where the proceeding is a creditors' winding-up, the court retains a measure of control. An exercise by the liquidator appointed by the creditors of certain type of powers, as previously mentioned, must be sanctioned by the court, or the committee of inspection, or (if there is no such committee), a meeting of the creditors. ${ }^{66}$ Where consent is required and the liquidator has exercised the power without the required sanction, the exercise of the power may be ratified by the court, not the Committee. ${ }^{67}$ Also, where the liquidator has made a sanction request to the creditors (represented by the committee of inspection or through a meeting of creditors), and the creditors have refused the request, the officeholder may seek sanction from the court. ${ }^{68}$

\section{Conclusion}

Lord Sumption's dicta in Singularis that the power is not available to assist a voluntary winding-up serves as a condition for recognising foreign insolvency proceedings (and, accordingly, the authority of the foreign officeholder) ${ }^{69}$ instead of a limit on the court's discretion to grant assistance. That recognition condition precludes the granting of judicial

\footnotetext{
${ }^{63}$ Singularis, above note 1, 1693, 1694 (per Lord Sumption).

${ }^{64}$ Ibid., 1696.

${ }^{65}$ Text to note 47 above $f f$.

66 Text to note 45 above.

${ }^{67}$ Re Associated Travel, Leisure and Services Ltd (in liq) [1978] 2 All ER 273.

${ }^{68}$ Re Luen Yick Water \& Drainage Works Ltd [2005] HKCFI 1289 (Unreported, HCCW 209/2002, 30 November 2005).

${ }^{69}$ Moss, Fletcher and Isaacs, above note 3, 100.
} 
assistance where the foreign proceeding is an insolvent voluntary winding-up. A refusal to grant assistance where the foreign proceeding is an insolvent voluntary winding-up is, however, inconsistent with modified universalism, which, according to Lord Sumption himself, is founded on the public interest in the:

"ability of foreign courts exercising insolvency jurisdiction in the place of the company's incorporation to conduct an orderly winding up of its affairs on a worldwide basis, notwithstanding the territorial limits of their jurisdiction."70

Where the proceeding is one of insolvency, the foreign court may exercise its insolvency jurisdiction, irrespective of the mode of the winding-up or whether the officeholder is courtappointed.

A refusal to grant assistance where the foreign proceeding is an insolvent voluntary windingup, at a practical level, will almost certainly increase the cost of a winding-up. The company, for example, may be forced to petition for a compulsory winding-up ${ }^{71}$ in the place of the company's incorporation and then to make a recognition and assistance application to the assisting court afresh. This course of action is likely to increase the costs for cross-border insolvency, as a compulsory winding-up is generally more expensive and time-consuming. ${ }^{72}$ The refusal of Aedit Abdullah JC and Harris J to adopt the Privy Council's distinction between voluntary and compulsory winding-up is therefore justified.

As the central constituent element of "foreign insolvency proceedings" is insolvency, the recognition test that Harris $\mathrm{J}$ has articulated is workable. However, to align the recognition test at common law with that under the Model law and to facilitate easy application, the element of court control should be added to Harris J's version of the common law recognition test.

\footnotetext{
${ }^{70}$ Singularis, above note $1,1696$.

71 A compulsory winding-up after the commencement of voluntary winding-up is possible: Re Goldcone Properties Ltd [2000] 2 HKLRD 16.

72 Stefan Lo and Charles Qu, Law of Companies in Hong Kong (3rd edn) (Sweet \& Maxwell, 2018), 1035.
} 


\section{University Library}

\section{- M I I N E R VA \\ A gateway to Melbourne's research publications}

Minerva Access is the Institutional Repository of The University of Melbourne

Author/s:

Qu, CZ;Godwin, A

Title:

Does the Common Law Power to Grant Cross-Border Insolvency Assistance Apply to an Insolvency Winding-up That is Voluntary? The Reaction to Singularis from Singapore and Hong Kong

Date:

2019

Citation:

Qu, C. Z. \& Godwin, A. (2019). Does the Common Law Power to Grant Cross-Border Insolvency Assistance Apply to an Insolvency Winding-up That is Voluntary? The Reaction to Singularis from Singapore and Hong Kong. International Insolvency Review: journal of the international association of insolvency professionals, 28 (3), pp.305-319. https:// doi.org/10.1002/iir.1348.

Persistent Link:

http://hdl.handle.net/11343/286808 